\title{
A strategy for rapidly making a DNA vaccine and treatment for disease caused by COVID19-Part three
}

\author{
George Pieczenik* \\ Rutgers University, School of Environmental and Biological Sciences, New Brunswick, N.J. 08901, USA
}

\section{Communication}

In Part 2 of our last paper on Rapidly Making a Vaccine and Treatment for the disease caused by Covid 19 we defined three possible epitopic sequences [1]. These three epitopic sequences were defined by a Kimura peptide analysis we developed to determine that selection for these sequences were on the amino acid sequence and not on the nucleotide sequence. This is evidence of the importance of these amino acid sequences to the survival of this virus for either binding or a function yet to be determined. These sequences are also on the surface of the virus as they have been identified by their being amino acid sequences identical to the SARS epitopes and bindable by antibodies.

In this paper, we take the three amino acid sequences and create a DNA sequence that can code for these three with the one unique characteristic is that the codons to be used are not the codons used by the virus but are codons that are most frequently used by human codings. These most frequently used human codons were identified by GenScripts algorithm and are listed in Table 1 below:

Using these codons we can back translate the three epitopic sequences identified in Part 2 of these papers. The GenScript algorithm was used for this back translation by Dr.Z.Hu.

These sequences inserted into pcNDA3.1(+) via KpnI and NotI with a CMV promoter ahead of them creates a human DNA vaccine that will replicate its product (GenScript). The total cost of making this vector which expresses the epitopic peptide that will create both antibodies in the patient, block Covid19 from binding and compete intracellularly with Covid19 is $\$ 240$ with shipping (GenScript, Dr. Z.Hu pers.comm). These DNA immunization vectors can be easily delivered as a gut microbe [2]. This is worth testing immediately.

Figure 1 shows the back translations with a terminator codon (tga) and a Kozak initiation sequence added (gccgccacc) [3].

These DNA sequences will be transcribed and translated into an epitopic amino acid sequence which will induce antibodies against Covid19. In addition, these amino acid sequence will bind competitively and block the necessary sites for Covid19 survival. Therefore these sequences can be used directly as a DNA vaccine [4].

In addition, these DNA sequences can also be inserted using CRISPR and transposon technology [5] as a continuous source of

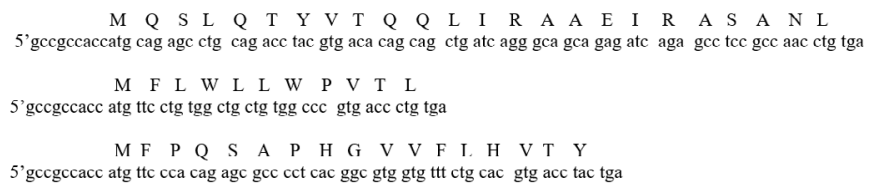

Figure 1. DNA vaccine for corona epitopes
Table 1. GenScript Codon Usage Frequency Table

\begin{tabular}{|c|c|}
\hline Human aa & Most frequently used human codon/aa \\
\hline $\mathrm{F}$ & TTC, TTT \\
\hline $\mathrm{L}$ & CTG \\
\hline $\mathrm{Y}$ & TAC \\
\hline $\mathrm{H}$ & $\mathrm{CAC}$ \\
\hline Q & CAG \\
\hline $\mathrm{I}$ & ATC \\
\hline M & ATG \\
\hline $\mathrm{N}$ & $\mathrm{AAC}$ \\
\hline $\mathrm{K}$ & AAG \\
\hline $\mathrm{V}$ & GTG \\
\hline $\mathrm{D}$ & GAC \\
\hline $\mathrm{E}$ & GAG \\
\hline $\mathrm{S}$ & AGC, TCC \\
\hline $\mathrm{C}$ & TGC \\
\hline TRM & TGA \\
\hline W & TGG \\
\hline $\mathrm{P}$ & $\mathrm{CCA}, \mathrm{CCT}$ \\
\hline $\mathrm{R}$ & AGG, AGA \\
\hline $\mathrm{T}$ & ACC \\
\hline A & GCC, GCA \\
\hline $\mathrm{G}$ & GGC \\
\hline $\mathrm{G}$ & GGC \\
\hline
\end{tabular}

blocking peptides and antigenic peptides. At some point, there will be a balance of antibodies formed against Covid19 and the amount of blocking peptide formed. At this point, the disease will be treated and the infectivity suppressed. These DNA sequences will compete with the Covid19 virus for sequences needed by both and will limit the ability of Covid19 to be expressed maximally without this Genotypic competition [6].

\section{References}

1. Pieczenik G (2020) "A strategy for rapidly making a vaccine and treatment for the disease caused by the Wuhan-Corona Virus 2019 (COVID19)-Part two". Med Case Rep Rev 3: 1-3.

2. Becker PD, Noerder M, Guzmán CA (2008) Genetic immunization: bacteria as DNA vaccine delivery vehicles. Human Vaccines 4: 189-202.

${ }^{*}$ Correspondence to: George Pieczenik, Rutgers University, School of Environmental and Biological Sciences, New Brunswick, N.J. 08901, USA, E-mail: piecze@sebs.rutgers.edu

Received: March 09, 2020; Accepted: March 17, 2020; Published: March 20, 2020 
Pieczenik G (2020) A strategy for rapidly making a DNA vaccine and treatment for disease caused by COVID19-Part three

3. Kozak M (1984) Compilation and analysis of sequences upstream from the translational start site in eukaryotic mRNAs. Nucleic acids research 12: 857-872.

4. Davis HL, McCluskie MJ (1999) DNA vaccines for viral diseases. Microbes Infect 1: 7-21.
5. Strecker J, Ladha A, Gardner Z, Schmid-Burgk JL, Makarova KS, et al. (2019) RNAguided DNA insertion with CRISPR-associated transposases. Science 365: 48-53.

6. Pieczenik G (1980) Predicting coding function from nucleotide sequence or survival of" fitness" of tRNA. Proc Natl Acad Sci 77: 3539-3543.

Copyright: (C2020 Pieczenik G. This is an open-access article distributed under the terms of the Creative Commons Attribution License, which permits unrestricted use, distribution, and reproduction in any medium, provided the original author and source are credited. 